\title{
引違い形式金属建具の気密水密試験
}

$\S 1$. 概 要

現在一般に引違い形式建具が多く用いられている。基 本的な鋼製引違い空、特殊締り機構をるつ鋼製引違い突 特よばアルミニウム製引違い空なぞの気密、水密試験を 行い、パッキングの効果、構造形式飞よる特性を明らか そした。試験装置および試験方法については既に発表し た通りである(1)(2)。試験を行つた引違い空は図 1 打よび 表 1 火示す。

\section{\$2. 気密試験}

\section{1 鋼製上車形式 (形式A)}

この建具の構造は図 1，a そ示すごとく、銅製建具引

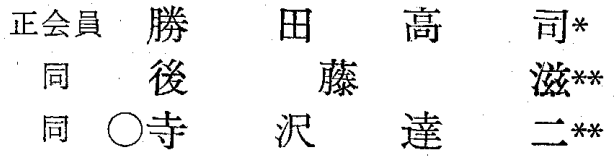
違い形式として一般と用いられているるのであ る。これについて、パッキングのない場合、縦 方向の戸当り括よび马合せ部分にだけパッキン グのある場合、建具框部分全部にパッキングを 用いた場合の 3 例につき試験を行つた。結果は 屈 $2 \sim$ 図 4 に示す。

パッキングのない場合は通気量が非常に多く なる。パッキングを縦方向の戸当り括よび召合 せ部分にだけに用いた場合の通気量はパッキン グのない場合のそれの約 $80 \%$ K低下している。 また、パッキングを框部分全部に用いた場合の 通気量はパッキングを使用しない場合のそれの $20 \%$ 程度に低下している。

部分通気量の測定結果は図 4 のごとくで、パ ッキングのない場合は図 4，a のよろ飞全体よ り漏る。パッキングを当り怙よび召合せ部分 だけ挿入した場合は図 $4, \mathrm{~b}$ のごとく縦方向の 気密度はよくなるが、上部括よび下部は縦方向 飞挿入したパッキングの影響で障子と空枠の接 合が悪くなり、通気量が逆に多くなつている。 パッキングが全框部分にある場合は図 4,c の ごとく全般的に気密度が高くなつている。

この建具の室外側より圧力が加つた場合と室 内側より圧力が加つた場合とでは、前者の方が 通気量は少ない。

2.2 鋼製気密上車形式 (形式 B)

この建具は引違い形式で気密度の高いことを 目的としたもので、図 $1, \mathrm{~b}$ に示すごとく障子
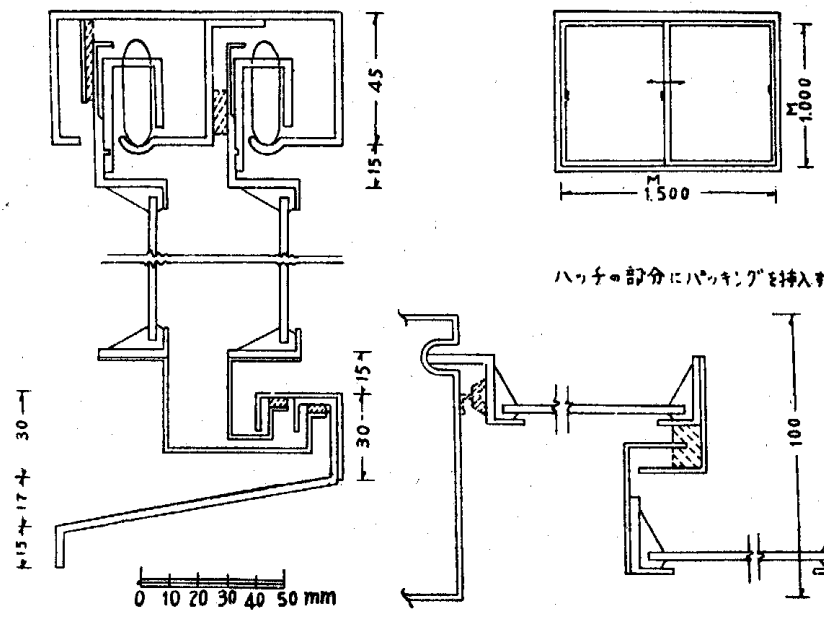

\begin{tabular}{|c|c|c|c|c|c|}
\hline 形式 & 造 & \begin{tabular}{|l} 
隙間長 \\
$\mathbf{m}$
\end{tabular} & 材 料 & パッキング & 䋨り形式 \\
\hline $\mathbf{A}$ & 上車引違い空 & 6.00 & 鋼 & な し & $\begin{array}{l}\text { 召合は中央ク } \\
\text { レント }\end{array}$ \\
\hline " & " & " & $"$ & $\begin{array}{l}\text { ネオプレンテ当 } \\
\text { りょび石合せ }\end{array}$ & " \\
\hline " & $"$ & $"$ & $"$ & $\begin{array}{l}\text { ホオプレン全櫵 } \\
\text { 部分 }\end{array}$ & " \\
\hline B & 気密上車引違い空 & 6.87 & $"$ & " & 特殊締り \\
\hline $\mathrm{C}$ & 下車引遠い空 & 9.46 & アルミ & パイル & $\begin{array}{l}\text { 戸当り中央クレ } \\
\text { 七ン }\end{array}$ \\
\hline
\end{tabular}

を締めると、障子の吊車がガイド板内側に笴り、障子全 体が空枠に密着する構造になつている。また、召合せ部 分のクレセントで 2 枚の障子をしうかりと締め合せてい 

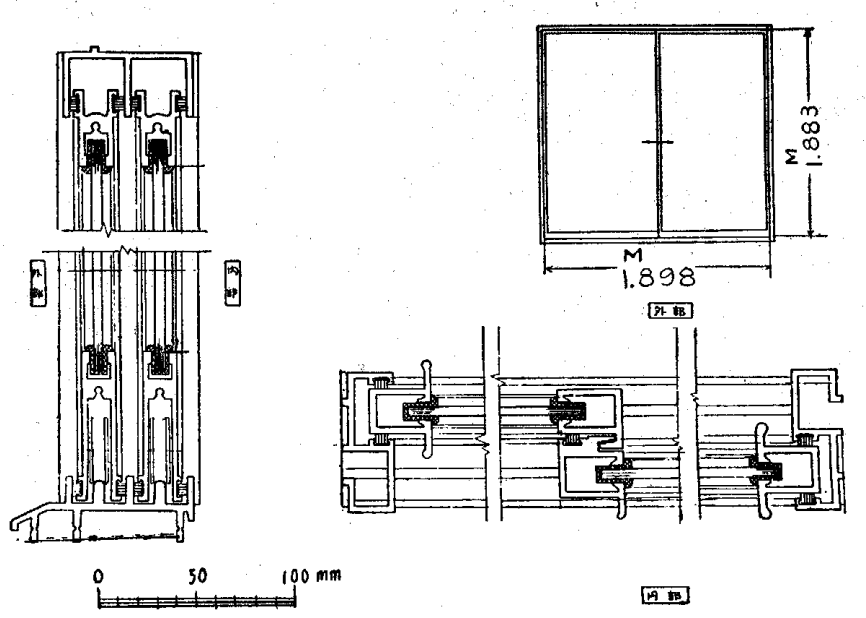

因间

図 1 (c)

る。この形式の気密度は高く、通気量は形式Aのパッキ ングのない場合の $5 \%$ 程度になつている。

部分通気量は図 5 のごとく非常によい結果を示してい る。

この建具につき室外側より圧力を加えたときと、室内 㑡より圧力を加光たときでは後者のときの通気量が多 い。この傾向は圧力差の大きい性ぞ顕著に表われる。こ れは、建具閉鎖時に障子が外から内に空枠へ寄せられる ような構造になつているために、室外側より圧力が加わ るときは、障子を空枠寄せ、室内側より圧力が加わる ときは障子を空模加ら離そうとするためである。

\section{3 アルミニューム製下車形式（形式C)}

アルミニューム製引違い空は重量が少いので、下車形 式の引違い空が多く使用されている。下車形式引違い空 として図 1,c 飞示すような形式Cについて測定を行つ た。測定結果は図 2 括よび図 3 亿示す。この結果は米国 アルミニューム管製造業者協会 (A.W.M.A.) 規格、压 力差、 $7.8 \mathrm{~mm}$ 水柱のとき通気量 $4.18 \mathrm{~m}^{3} / \mathrm{hr} \cdot \mathrm{m}$ 以下の 值で、気密度の高いととを示している。また、敷居に設 けられている排水孔よの通気量は圧力差、 $1 \mathrm{~mm}$ 水柱 で約 5 割、压力差 $20 \mathrm{~mm}$ 水柱で約 2 割程度になつて、 排水孔よりの通気量が多いが、全体の通気量訬ない。

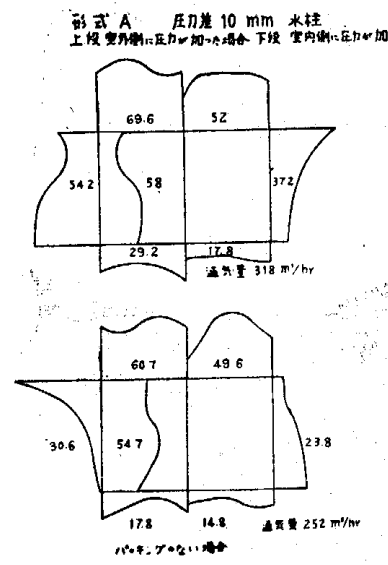

(a)
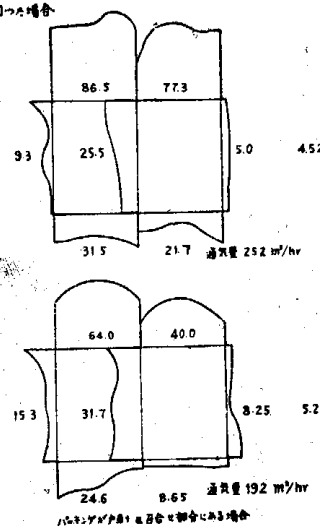

(b)
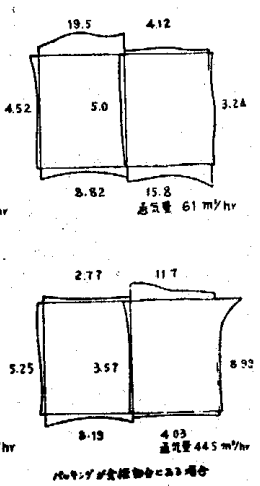

(c)

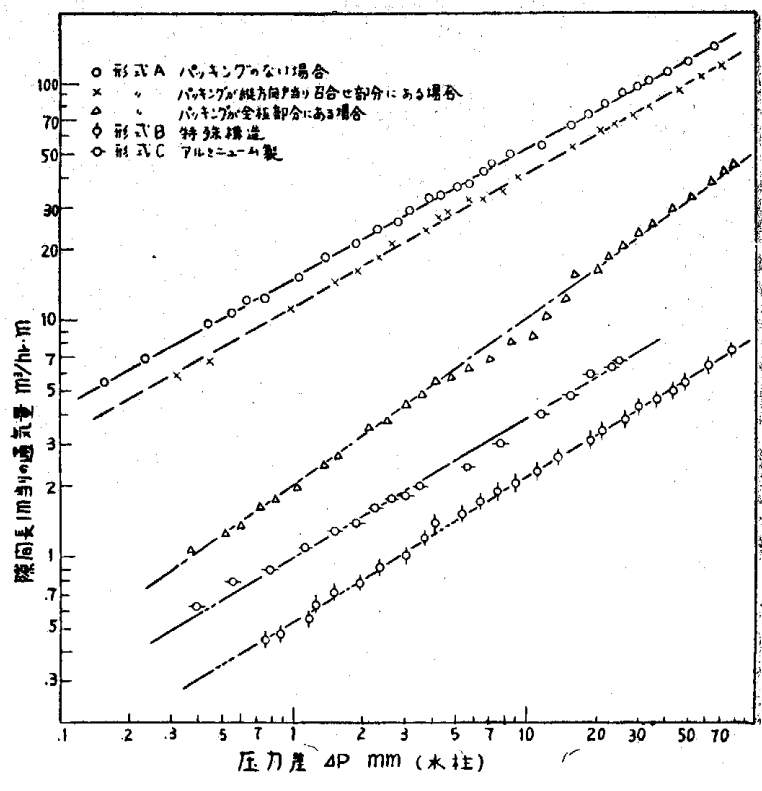

図 2

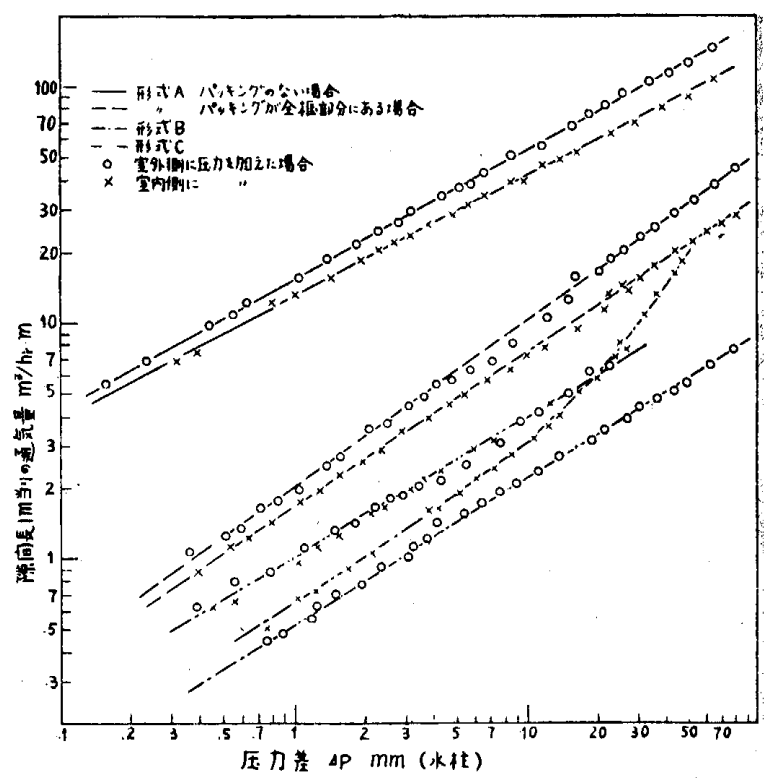

图 3

部分的には戸当り招よび召合せ下部より激しく漏つてい る。

室外側より圧 力を加えたとき と室内側より圧 力を加えたとき の通気量は注 一致している。 これは構造上ど ちら側より風圧 を受けて子寒势 と障子の接合条 件が同じになる ためである。

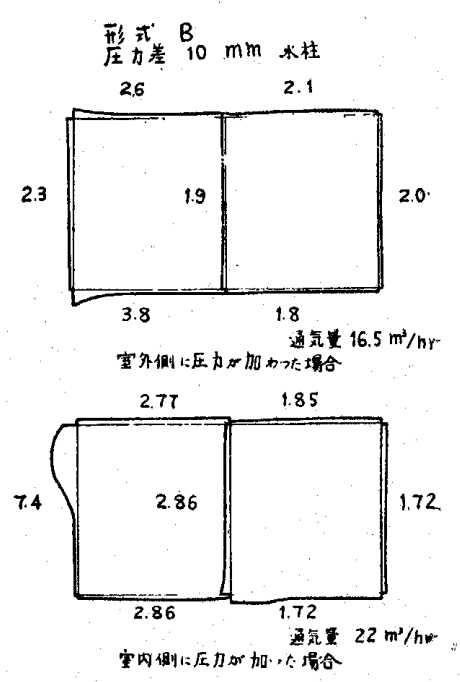

図 5 


\section{4 総 括}

（a）パッキングのない鉄製引違い建具の通気量 パッキングのない場合の銅製上車形式引違い空につい て、現在まで数種類測定した結果、その通気量は形式A 飞近い值を示していた。現在一般て使用されている上車 形式でパッキングのない引違い突の通気量として、形式 Aのパッキングのない場合の值を採用してよいと思われ る。

\section{（b）パッキングの効果}

引違い㥶にパッキングを用いるとき、月当り稆よび召 合せ部分にだけパッキングを插入した場合の通気量はパ ッキングのない場合の約 $80 \%$ で、あをり效果が上らな い。框部分全体にパッキングを雨入すればパッキングの ない場合の約 $20 \%$ そなり、パッキングの効果が大であ る。パッキングを使用する場合は、隙間部分全体に霄入 すべきである。

（c）引違い形式と他の開閉形式のの比較

形式 $\mathrm{A} 、$ 形式 $\mathrm{B}$ 和よび形式 C の引違い建具飞対して、 他の開閉形式の建具飞ついて行つた試験結果を図 6 （図 中 $A, B, C$ 形式 $A 、 H$ \&形式B、F形式C)飞示す。 このうち、上げ下げ空 D，E は一般に使用されている構 造のものであるが、引違い形式の通気量よりも少い通気 量を示している。このようと引違い形式のものは気密度 が低い。またパッキングの使用によつて、ある程度まで は気密度を高めることは出来るが、単にパッキングの插
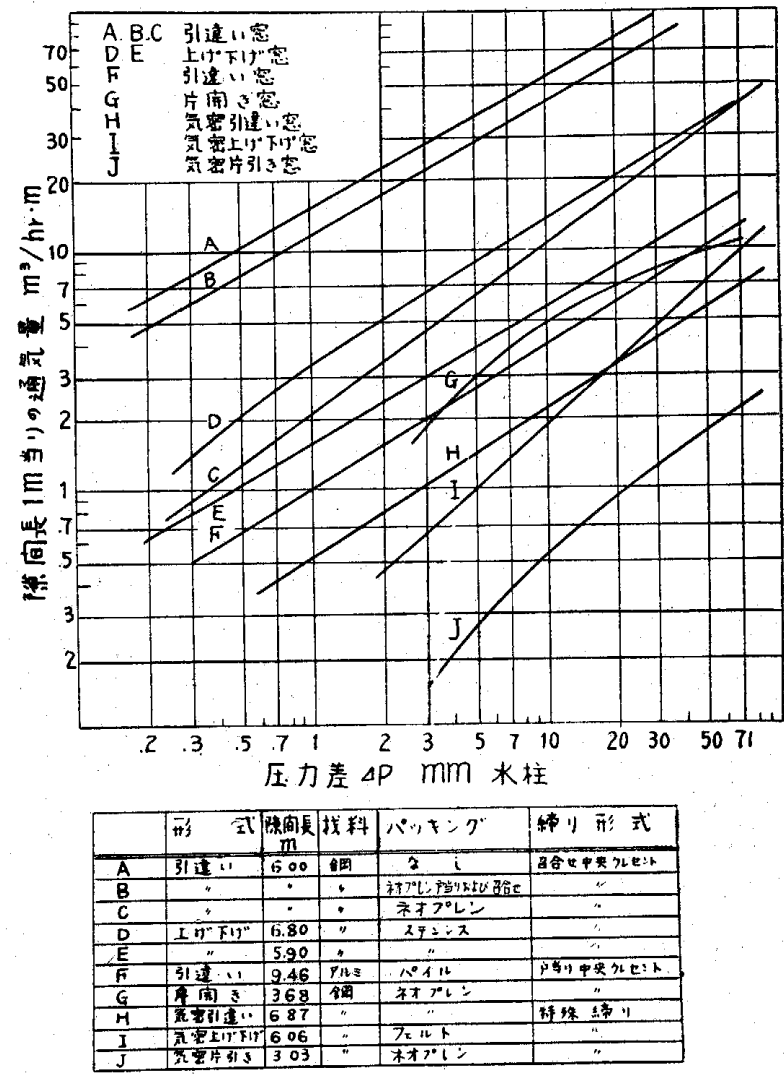

図 6
入により気密度を高めると障子の作動が重くなる。これ を防ぐには形式のような構造によらねばならない。 た、引違い形式は気密性の点で開き形式よりる数段劣る ようである。

\section{§3. 水密試験}

水密試験は各建具の前面飞噴霧する水量を $12 l / \mathrm{min}$ 扝 よび $20 \mathrm{l} / \mathrm{min}$ として行う。噴霧水量がある程度以上飞 なればそれ以上水量を増してる漏水状態に変化はなく、 建具の前後江加わる圧力差飞より漏水を生ずる。

3.1 鋼製上車形式 (形式 $\mathrm{A}$ )

この建具放いて漏水と圧力差の関係を図 7 亿示す。
$2 \mathrm{~mm}$

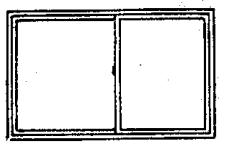

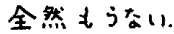

$5 \mathrm{~mm}$

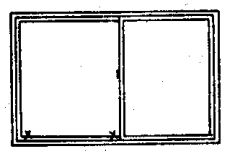

わづかにもる

$10 \mathrm{~mm}$

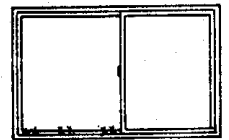

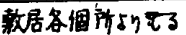

図 1
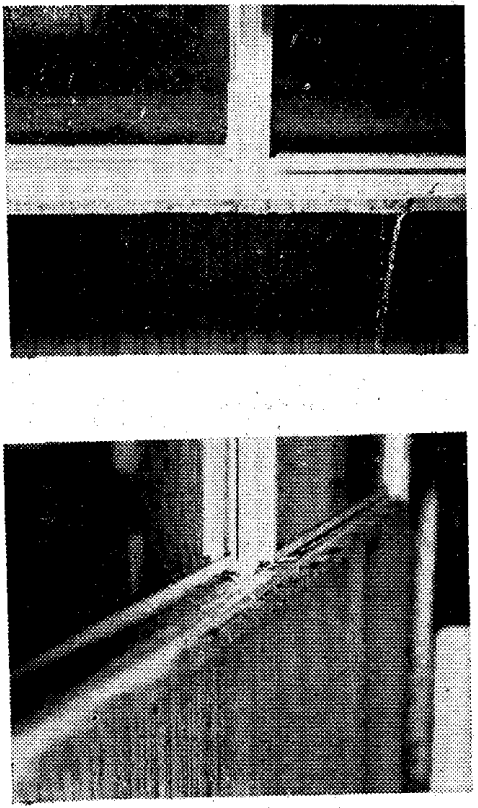

写真-1
$15 \mathrm{~mm}$

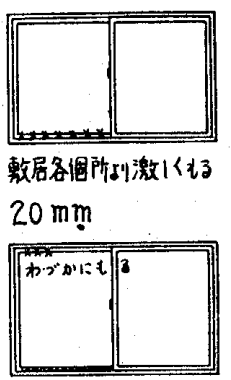

数居吅溢水する
圧力差 $4 \mathrm{~mm}$ 以下では漏水 しない。圧力 差 $5 \sim 15 \mathrm{~mm}$ で雨返し部分 飞水が侵入 し、召合せ下 部より泡招よ び沫となり、 時々敷居を越 えて内部飛 水量 $12 \mathrm{l} / \mathrm{min} 20 \mathrm{l} / \mathrm{min}$ 出す。圧力差 压力差 $\mathrm{mm}$ 水柱

$20 \mathrm{~mm}$ 以上 になると敷居 を越えて内部 に溢水する（写真一 1 参照)。

3.2 鋼製気密上 車形式 (形式 B)

この建具々ついて 漏水と压力差の関係 を図 8 亿示す。圧力 差 $8 \mathrm{~mm}$ 程度まで、 雨返し部分に水が浸 入することはない。 圧力差 $10 \sim 30 \mathrm{~mm}$ で、雨返し部分飞水 が浸入してくるが敷 居を越劣ることはな い。庄力差 $40 \mathrm{~mm}$ 以上になると水が敷 居を越えて湓水し、

内部飞浸水してくる。

3.3 アルミニューム製下車形式 (形式C)

$ア ル ミ ニ ュ ー ム$ 線建具の水密試験結果は図 9 に示すご とくになる。圧力差 $5 \mathrm{~mm}$ で戸当り括よび召合せの下隅 よりわづか消水し、敷居溢を流れて排水孔より排水す 
る。死力差 $15 \mathrm{~mm}$ では戸当り括よび马合せ下部よ り漏水し、敷居溝を流れて排水孔より流れ出るが、 時々、排水孔より沫きとなり吹出す。また縦框と 下框の突付け部分近くの下框グレージング、チャ ンネル部

分より水 が唀す る。压力 差 $25 \mathrm{~mm}$ で、户当 $10 \mathrm{~mm}$

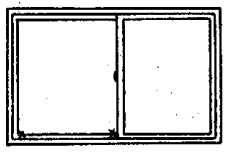
わづかにもる

り报よび 召合せの

下部より の漏水が 激しくな $20 \mathrm{~mm}$

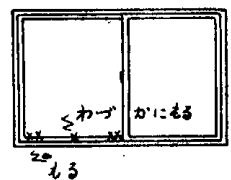

り、また
$30 \mathrm{~mm}$

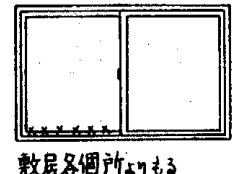

$40 \mathrm{~mm}$

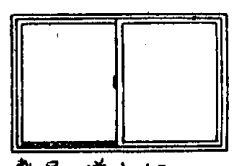

教居江溢k+3

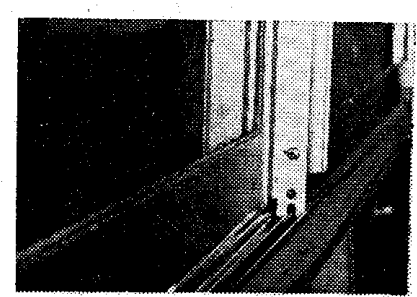

压力盖 $5 \mathrm{mn}$ 水挂

写直一2.

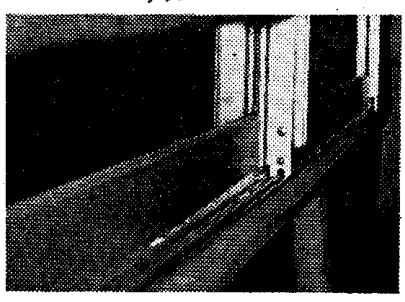

代力羓100n本 军 1 - 2 . D

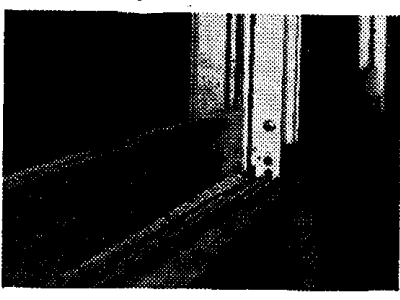

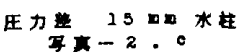

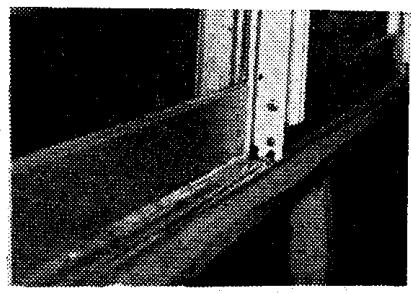

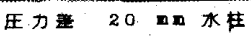

宣 $x-2 \cdot d$

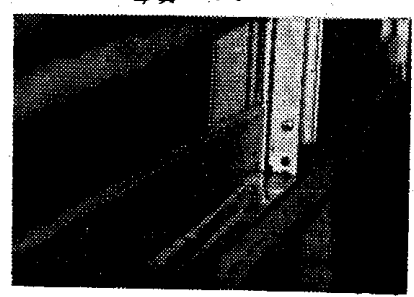

生力童 25 吅本 要立-2.

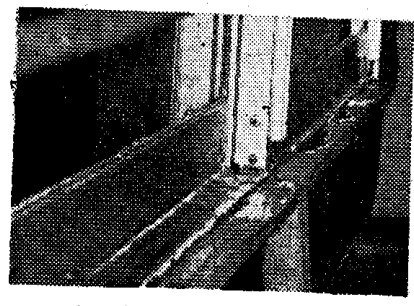

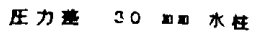
7 $5-2: 1$

军真-2

居を越学て、内側飞飛出す。次第に排水孔に水が満ち、

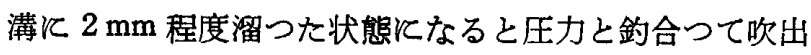
さなくなる。圧力差 $25 \mathrm{~mm}$ で、排水孔より激しく沫き となり吹出し、吹出した水滴は敷居を越てて内部に飛出 す。溝に $7 \mathrm{~mm}$ 程度溜まると排水孔より吹出さなくな る。圧力差 $32 \mathrm{~mm}$ では、排水孔より浸入した水は敷居 を越えて溢水する。しかし、この圧力差でもパイルより の浸水はなかつた。

\section{4 総 括}

形式 A は圧力差 $20 \mathrm{~mm}$ 、形式 B は圧力差 $40 \mathrm{~mm}$ 、形 式C柱圧力差 $30 \mathrm{~mm}$ で溢水する。この溢水状態を考え

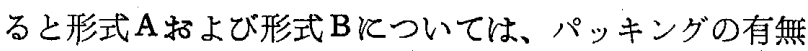
はあまり関係なく、建具に障子下框下部ガイド板から雨 返し上端までの高さ以上の水柱に相当する圧力が加わる と溢水が行われるようである。形式Cについては、戸当 り括よび召合せ下部などよりの漏水は圧力差がわずかで も行われ、敷居溝に落ちる。敷居溝に溜つた水は建具に 加わる圧力差が排水孔下端より敷居上端までの高さ以下 の水柱に相当すれば、排水孔より排水される。これ以上の 水柱に相当する圧力差であれば敷居上端より溢水する。

\section{謝 辞}

供試空を製作された不二製作所，日軽アルミニウム工業各社の御協力 に対して深く感謝する

[文献]

（1）勝田，後藤，寺沢：日本建築学会諭文報告集54号 $481 / 4841956$

(2) 同上 日本建筑学会研究報告45号 $37 / 40 \quad 1959$

形式 C水量 $12 \ell / \mathrm{min} 20 \mathrm{l} / \mathrm{min}$

压力差 $\mathrm{mm}$ 水柱

図 9 